\title{
Wieloletnie trawy z rodzaju Miscanthus Anderss. - przykłady prac własnych
}

\author{
Perennial Grasses of the genus Miscanthus Anderss. - examples of own work
}

\section{Sandra Cichorz ${ }^{\bowtie}$, Maria Gośka}

Pracownia Cytogenetyki i Metodyki Hodowli, Zakład Genetyki i Hodowli Roślin Korzeniowych, Instytut Hodowli i Aklimatyzacji Roślin - Państwowy Instytut Badawczy, Oddział w Bydgoszczy

e-mail: s.cichorz@ihar.bydgoszcz.pl

\begin{abstract}
Podsumowano najważniejsze osiągnięcia dotyczące cytogenetycznej i molekularnej charakterystyki wybranej puli genotypów miskanta chińskiego, cukrowego oraz olbrzymiego uzyskanych w Pracowni Cytogenetyki i Metodyki Hodowli, Zakładu Genetyki i Hodowli Roślin Korzeniowych, Oddziału IHAR — PIB w Bydgoszczy.

Słowa kluczowe: identyfikacja gatunkowa, mikrorozmnażanie, miskant, wielkość genomu, zróżnicowanie genetyczne

Summaries of the most important achievements concerning the cytogenetic and molecular characteristics of the selected pool of Chinese, sugar and giant Miscanthus genotypes obtained in the Laboratory of Cytogenetics and Methods of Breeding, Plant Genetics and Plant Breeding, Division IHAR-PIB in Bydgoszcz.
\end{abstract}

Key words: species identification, micropropagation, miscanthus, genome size, genetic diversity

W Europie do końca XX wieku wieloletnie trawy $\mathrm{z}$ rodzaju Miscanthus Anderss. postrzegano głównie jako rośliny ozdobne. Jak podają dane literaturowe, najprawdopodobniej pierwsza plantacja o powierzchni zaledwie jednego hektara została założona w 1982 roku w Möser (okolice Magdeburga, Niemcy) (Jeżowski, 1999; Chung i Kim, 2012). Dało to początek intensywnym badaniom i obserwacjom polowym dotyczącym potencjału plonotwórczego wybranych gatunków miskanta oraz wpłynęło na rozpowszechnienie tej rośliny $w$ innych częściach Europy, a także w Ameryce Północnej. Obecnie, gatunki $M$. sinensis, $M$. sacchariflorus, a w szczególności $M . \quad \times$ giganteus stały się jednym $\mathrm{z}$ najbardziej obiecujących surowców do produkcji biomasy $\mathrm{z}$ przeznaczeniem na cele energetyczne, a także do wykorzystania w przemyśle celulozowym, budowlanym czy meblarskim. Niewielkie zapotrzebowanie na składniki odżywcze sprawia, że wybrane genotypy mogą być uprawiane na gruntach marginalnych lub poprzemysłowych terenach wyrobisk (Sacks i in., 2013).

$\mathrm{Z}$ uwagi na całkowitą lub częściową bezpłodność miskant olbrzymi, jako triploidalny mieszaniec międzygatunkowy, w warunkach klimatu umiarkowanego nie wytwarza nasion i rozmnażany jest wyłącznie wegetatywnie. Wpływa to na znaczne zawężenie puli genetycznej tego gatunku (Lafferty i Lelley, 1994; CliftonBrown i in., 2008). Dodatkowe niejasności i dezorientację może wprowadzać niejednoznaczna nomenklatura używana do określenia poszczególnych klonów miskanta olbrzymiego, jak również gatunków w obrębie rodzaju Miscanthus (Hodkinson $\mathrm{i}$ in., 2015). Jedne $\mathrm{z}$ pierwszych wyników badań zróżnicowania w obrębie $M$. × giganteus sugerują, że w Europie dostępne są zaledwie dwa lub maksymalnie trzy różniące się od siebie genotypy miskanta olbrzymiego (Greef i in., 1997, Hodkinson i in., 2002). Nie da się jednakże wykluczyć, iż europejskie uprawy miskanta olbrzymiego bazują wyłącznie na jednym i tym samym genotypie, który pierwotnie przywieziono z Dalekiego Wschodu (Deuter i Jeżowski 1998). Wykorzystanie wyłącznie jednego klonu podczas zakładania plantacji jest ryzykowne ze względu na specyficzne wymagania co do cech jakości związanych z przeznaczeniem surowca oraz duże ryzyko zniszczenia całej plantacji $\mathrm{W}$ przypadku pojawienia się patogenów (Clark i in., 2014). Stąd istotnego znaczenia nabiera właściwy dobór materiału do prowadzenia uprawy. Wymaga to jednak odpowiedniej identyfikacji 
poszczególnych genotypów, co $\mathrm{w}$ powyższym przypadku nie jest możliwe do wykonania jedynie na podstawie oceny morfologicznej.

\section{Charakterystyka zróżnicowania genetycznego wybranych gatunków z rodzaju Miscanthus}

Ze względu na brak weryfikacji przynależności gatunkowej oraz charakterystyki zróżnicowania genetycznego sadzonek gatunków z rodzaju Miscanthus dostępnych na polskim rynku, wykonano cytogenetyczną i molekularną charakterystykę wybranej puli genotypów miskanta chińskiego, cukrowego oraz olbrzymiego.

Celem badań było opracowanie wiarygodnych i powtarzalnych profili DNA pozwalających na identyfikację osobniczą i gatunkową miskanta. Ponadto przeprowadzono ocenę zróżnicowania klonów, ekotypów oraz odmian trzech gatunków rodzaju Miscanthus: $M$. $\times$ giganteus (4 klony), M. sinensis (12 odmian) oraz M. sacchariflorus (2 ekotypy) z zastosowaniem markerów molekularnych ISSR i RAPD. Materiał i metody szerzej opisano w pracy Cichorz i in. (2014).

Obydwa systemy markerów molekularnych pozwoliły na identyfikację osobniczą miskanta. Do tego celu wystarczyło użycie jednego startera ISSR (ISSR1) lub trzech starterów RAPD (RAPD1, RAPD2, RAPD4). Ponadto zastosowanie powyższych metod zweryfikowało klasyfikację genotypu błędnie oznaczonego jako M. floridulus, który prawidłowo przyporządkowano do gatunku $M . \times$ giganteus. Dla każdego z osobników miskanta olbrzymiego wytypowano unikalne produkty: jeden dla klonu niemieckiego, dwa dla klonu kanadyjskiego i angielskiego oraz pięć dla klonu kwiecistego.

W wyniku przeprowadzonych reakcji wytypowano produkty umożliwiające identyfikację gatunkową. Łącznie uzyskano 7 prążków (4 ISSR oraz 3 RAPD) występujących wyłącznie u miskanta olbrzymiego, zaś nieobecnych u pozostałych genotypów, 1 produkt (ISSR) charakterystyczny dla miskanta chińskiego oraz 8 (5 ISSR i 3 RAPD) typowych dla miskanta cukrowego.

Wartość współczynnika podobieństwa genetycznego wyznaczona na podstawie obydwu systemów markerów łącznie w przypadku $M$. × giganteus wyniosła 0,94 . Nieco niższą wartość wykazały genotypy $M$. sacchariflorus - 0,82, zaś najniższą oszacowano dla odmian $M$. sinensis - 0,61. Wartość współczynnika podobieństwa genetycznego błędnie oznaczonego genotypu $M$. floridulus była najwyższa w odniesieniu do gatunku $M . \times$ giganteus i wyniosła 0,74 . Powyższe wyniki miały swoje potwierdzenie $\mathrm{w}$ dendrogramach oraz na wykresie analizy PCoA, na podstawie których można stwierdzić, że wszystkie badane osobniki zostały pogrupowane $\mathrm{w}$ trzy główne skupienia, zgodnie $\mathrm{z}$ przynależnością gatunkową, $\mathrm{z}$ wyjątkiem $M$. floridulus, który występował w tym samym skupieniu co $M$. × giganteus. W obrębie gatunku miskanta olbrzymiego najbardziej zbliżone genetycznie były klony niemiecki i kanadyjski. Klon angielski różnił się znikomo, zaś najbardziej oddalony okazał się klon kwiecisty. Ponadto analiza skupień wykazała, że gatunek miskanta olbrzymiego był bardziej zbliżony do gatunku miskanta cukrowego niż chińskiego.

Podsumowując, opracowane warunki prowadzenia reakcji $\mathrm{z}$ markerami ISSR oraz RAPD pozwolity na identyfikację wybranych klonów, ekotypów, odmian i gatunków $M$. × giganteus, M. sinensis oraz M. sacchariflorus. Markery molekularne ISSR wykazały wyższy poziom polimorfizmu oraz szerszy zakres wielkości produktów, a tym samym okazały się bardziej efektywne do identyfikacji osobniczej i gatunkowej miskanta niż markery molekularne RAPD. Użycie 1 startera ISSR oraz 3 starterów RAPD było wystarczające do identyfikacji osobników miskanta należących do kolekcji polowej IHAR - PIB. W obrębie analizowanej puli genetycznej miskanta olbrzymiego zaobserwowano bardzo niskie zróżnicowanie genetyczne, co najprawdopodobniej wskazuje na wspólne źródło pochodzenia trzech spośród czterech klonów. Ekotypy miskanta cukrowego wykazały relatywnie niskie zróżnicowane, natomiast między odmianami miskanta chińskiego odnotowano duże zróżnicowanie genetyczne.

\section{Międzygatunkowe i wewnątrzgatunkowe zróżnicowanie wielkości genomu wybranych gatunków z rodzaju Miscanthus}

Głównym celem pracy była ocena międzygatunkowego i wewnątrzgatunkowego zróżnicowania zawartości jądrowego DNA u trzech gatunków miskanta: M. $\times$ giganteus (4 klony), M. sinensis (12 odmian) oraz M. sacchariflorus (2 ekotypy) z wykorzystaniem cytometrii przepływowej. Zweryfikowano wykorzystanie powyższego parametru do identyfikacji gatunkowej poszczególnych osobników. Na podstawie 
oszacowanej wielkości genomu monoploidalnego (1Cx) analizowanych genotypów określono możliwość wytypowania potencjalnych komponentów rodzicielskich $\mathrm{z}$ rodzaju Miscanthus używanych do krzyżowań. Oceniono przydatność pomiaru długości aparatów szparkowych do precyzyjnego wyznaczenia stopnia ploidalności roślin miskanta, która została potwierdzona oznaczeniem liczby chromosomów (Cichorz i in., 2015).

Dla wszystkich analizowanych osobników zawartość 2C DNA zawierała się w przedziale od 4,58 pg do 8,34 pg i umożliwiła weryfikację ich przynależności gatunkowej. Najwyższa wielkość genomu była obserwowana u triploidalnego miskanta chińskiego odmiany 'Goliath' $(8,34 \mathrm{pg} ; 2 \mathrm{n}=3 \mathrm{x}=57)$, który przypuszczalnie powstał $\mathrm{w}$ wyniku skrzyżowania diploidalnego $\mathrm{i}$ tetraploidalnego miskanta chińskiego. W przypadku triploidalnych genotypów miskanta olbrzymiego $(2 \mathrm{n}=3 \mathrm{x}=57)$ (najprawdopodobniej krzyżówka diploidalnego miskanta chińskiego $\mathrm{z}$ tetraploidalnym miskantem cukrowym) średnia zawartość jądrowego DNA wyniosła 7,43 pg i istotnie różniła się od odmiany 'Goliath', co dodatkowo potwierdziło przypuszczenie o odmiennej kompozycji rodzicielskiej tych mieszańców. Pośrednie wartości uzyskano dla diploidalnych miskantów chińskich $(5,52-5,72 \mathrm{pg} ; 2 \mathrm{n}=2 \mathrm{x}=$ 38 ), zaś istotnie niższe wartości obserwowano u diploidalnych ekotypów miskanta cukrowego (4,58 i 4,59 pg; $2 n=2 x=38$ ). Przeprowadzone analizy potwierdziły, że różnice $\mathrm{w}$ zawartości $2 \mathrm{C}$ DNA, a także wielkości genomu monoploidalnego $(1 \mathrm{Cx})$ między trzema gatunkami miskanta są istotne statystycznie $(\mathrm{P}<0,01)$. Natomiast istotne zróżnicowanie wewnątrzgatunkowe zaobserwowano wyłącznie w obrębie miskanta chińskiego. Odmiany o największym genomie: 'Sirene', 'Graziella' oraz 'Variegatus' $(5,72 \pm 0,04$ pg) miały o około $4 \%$ wyższą zawartość $2 \mathrm{C}$ DNA niż odmiana o najmniejszym genomie ('Malepartus' — 5,52 $\pm 0,01 \mathrm{pg}$ ).

Analiza wariancji długości aparatów szparkowych wykazała istotne różnice pomiędzy poszczególnymi osobnikami, zaś średnie wartości w obrębie gatunku miskanta olbrzymiego, chińskiego oraz cukrowego wyniosły odpowiednio: $30,88 \mu \mathrm{m}, 27,10 \mu \mathrm{m}, 25,05 \mu \mathrm{m}$. Najdłuższe aparaty szparkowe zaobserwowano u miskanta chińskiego 'Goliath' (33,62 $\mu \mathrm{m})$, a najkrótsze u 'Gracillimus' $(23,57 \mu \mathrm{m})$. Korelacja pomiędzy długością aparatów szparkowych, stopniem ploidalności oraz zawartością
2C DNA okazała się silna, zaś korelacja dla zawartości 2C DNA, stopnia ploidalności oraz liczby chromosomów okazała się bardzo silna. Biorąc pod uwagę brak istotnych różnic pomiędzy długością aparatów szparkowych triploidalnych genotypów miskanta olbrzymiego: 'Great Britain' (średnio 30,70 $\mu \mathrm{m}$ ) oraz 'Canada' (średnio 29,67 $\mu \mathrm{m}$ ), a diploidalnym miskantem chińskim 'Graziella' (średnio 29,96 $\mu \mathrm{m}$ ) oznaczenie stopnia ploidalności na podstawie długości aparatów szparkowych bywa nieprecyzyjne i może prowadzić do błędnych wniosków.

Reasumując, analizy cytometryczne potwierdziły istotne zróżnicowanie wielkości genomu miskanta na poziomie międzygatunkowym, a także w obrębie odmian miskanta chińskiego. Stwierdzono istotne różnice $\mathrm{w}$ zwartości $2 \mathrm{C}$ DNA oraz wielkości genomu monoploidalnego (1Cx) między trzema gatunkami miskanta. Wśród odmian miskanta chińskiego występowała istotna statystycznie wewnątrzgatunkowa zmienność $\mathrm{w}$ wielkości genomu na poziomie około 4\%. Różnice w wielkości genomu trzech gatunków miskanta umożliwiły identyfikację mieszańców i potwierdzenie odmiennych komponentów rodzicielskich w przypadku triploidalnych klonów miskanta olbrzymiego oraz miskanta chińskiego odmiany 'Goliath'.

\section{Literatuta}

Chung J. H., Kim D. S. 2012. Miscanthus as a Potential Bioenergy Crop in East Asia. J Crop Sci. Biotech 15: $65-77$.

Cichorz S., Gośka M., Litwiniec A. 2014. Miscanthus: genetic diversity and genotype identification using ISSR and RAPD markers. Mol Biotechnol 56: 911 924.

Cichorz S., Gośka M., Rewers M. 2015. Miscanthus: inter - and intraspecific genome size variation among $M . \times$ giganteus, $M$. sinensis, $M$. sacchariflorus accessions. Acta Biol Cracov Bot 57: 104 - 113.

Clark L. V., Brummer J. E., Głowacka K., Hall M. C., Heo K., Peng J., Yamada T., Yoo J. H., Yu C. Y., Zhao H., Long S. P., Sacks E. J. 2014. A footprint of past climate change on the diversity and population structure of Miscanthus sinensis. Ann Bot-London 114: $97-107$.

Clifton-Brown J. C., Chiang Y. Ch., Hodkinson T.R. 2008. Miscanthus: Genetic Resources and Breeding Potential to Enhance Bioenergy Production. W: Genetic Improvement of Bioenergy Crops. Red. W. Vermerris. Springer, Gainesville: $273-293$.

Deuter M., Jeżowski S. 1998. Szanse i problemy hodowli traw z rodzaju Miscanthus jako roślin alternatywnych. Hod. Rośl. Nasien. 2: $45-48$.

Greef J. M., Deuter M., Jung C., Schondelmaier J. 1997. Genetic diversity of European Miscanthus species revealed by AFLP fingerprinting. Genet Resour Crop Ev. 44: 185 - 195 . 
Hodkinson T. R., Chase M. W., Renvoize S. A. 2002. Characterization of a genetic resource collection for Miscanthus (Saccharinae, Andropogoneae, Poaceae) using AFLP and ISSR PCR. Ann Bot-London 89: 627 $-636$.

Hodkinson T. R., Klaas M., Jones M. B., Prickett R., Barth S. 2015. Miscanthus: a case study for the utilization of natural genetic variation. Plant Genet Resour-C 13: 219 $-237$.

Jeżowski S. 1999. Miskant chiński (Miscanthus sinensis (Thunb.) Andersson) — źródło odnawialnych i ekologicznych surowców dla Polski. Zeszyty Problemowe Postępów Nauk Rolniczych 468: 159 166.
Lafferty J., Lelley T. 1994. Cytogenetic studies of different Miscanthus species with potential for agricultural use. Plant Breeding 113: 246 - 249.

Sacks E. J., Juvik J. A., Lin Q., Stewart J. R., Yamada T. 2013. The gene pool of Miscanthus species and its improvement. In: Genomics of the Saccharinae, Plant Genetics and Genomics: Crops and Models. Ed. A. H. Paterson, Springer Science + Business Media, New York, str. $73-100$.

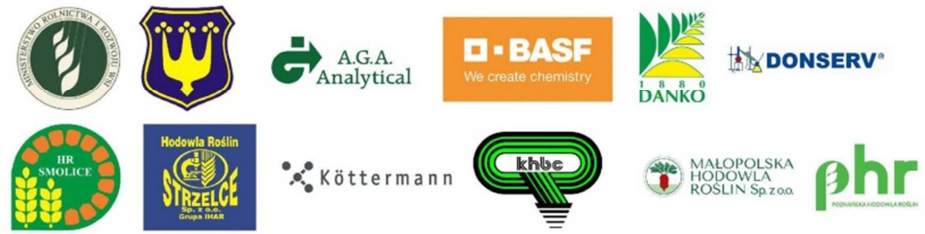

